DOI https://doi.org/10.32405/2522-9931-7(36)-9-20

УдК 159.9:316.61

Olena Bondarchuk,

Dr Prof, Head of Department of Management Psychology,

SHEI «University of Educational Management»,

Kyiv, Ukraine.

ORCID iD: https://orcid.org/0000-0003-3920-242X

bei.07@ukr.net

\title{
THE FEATURES OF TEACHERS' INNER FREEDOM WITH DIFFERENT LEVELS OF PSYCHOLOGICAL SAFETY OF THEIR EDUCATIONAL ENVIRONMENT
}

\begin{abstract}
The article deals with the problem of the correlation between teachers' inner freedom and psychological safety of the educational environment of the school. The key contradictions of the position of the Ukrainian teachers which can reduce their inner freedom and adversely affect on the psychological safety of the educational environment are determined. The essence and basic indicators of teachers' inner freedom and psychological safety of the educational environment of secondary schools are revealed.

The relationship between the inner freedom of teachers and the safety of the educational environment has been investigated. The distinctive features and factors of teachers' inner freedom and psychological safety of their educational environment are found. As a result of the empirical study of the inner freedom of teachers of secondary school from all regions of Ukraine, are found an insufficiently high level of the inner freedom and psychological safety of educational environment for a significant number of educators. The features of manifestations of inner freedom of teachers and psychological safety of the educational environment of school depending on their gender and work experience are defined.

It is shown that psychological safety of educational environment is a significant factor in the personal development of teachers, in particular, their inner freedom. There are correlations between psychological safety of educational environment and indicators of teachers' inner freedom such as self-efficacy, the personal value of inner freedom, professional autonomy and subjective well-being.

The investigation findings can be used in to elevate inner freedom Ukrainian teachers' by means of special training courses in the system of post-graduate pedagogical training is stated.
\end{abstract}


Key words: teacher, inner freedom, educational environment, psychological safety, subjective well-being.

\section{INTRODUCTION / ВCTУП}

Statements of problem. In the context of educational reforms, educational institutions need a teacher capable of educating a pupil as a citizen, a person, an innovator who can constructively transform the world, freely choose and build his life path, realize personal and spiritual potential. This poses increased demands on the personal characteristics (in particular, inner freedom) of teachers, which should be a model for pupils.

However, there are key contradictions of the position of the Ukrainian teachers which can reduce their inner freedom and adversely affect on the psychological safety of the educational environment:

- the contradiction between high positional requirements and actual educationists' status;

- the contradiction between the necessity to make independent and innovative decisions and considerable limitations of independence by superiors;

- the contradiction between the necessity to educate a unique and independent personality capable of constructive acting under sustained socioeconomic changes and a set of social norms and values peculiar to a given culture;

- the contradiction between the profession's personality-related requirements and the teacher's actual level of preparedness to perform professional functions, etc [3].

Analysis of recent research and publications. The personal inner freedom is investigated as a person's awareness of his ability and willingness to act, to freely make choices, to make decisions and to manage his life in accordance with his own meanings and values (G. Ball [7]; A. Sen [15], V. Chornobrovkina [9] etc.).

The experience of psychological safety is stated as one of the important conditions for the formation, full functioning and development of a free personality in society (I. Baeva, I. Yakimanska [1], etc.). At the same time, the main focus of the researchers is on the psychological safety of the educational environment for pupils and students (0. Eliseyeva [6], T. Shcherbakova [10], etc.); instead, the psychological safety and inner freedom of the personnel of educational organizations is much less studied.

That is why the study of the inner freedom of educators which correlate toward to the psychological safety of their educational environment is important. 


\section{AIM AND TASKS / META TA ЗАВДАННЯ}

The aim of the investigation is to find out the levels of teachers' inner freedom and their correlation with psychological safety of the educational environment of the school.

The tasks of the investigation are: 1) to study levels of teachers' inner freedom and psychological safety of the educational environment of their school; 2) to find out correlation of levels of teachers' inner freedom and psychological safety of the educational environment.

\section{THE THEORETICAL BACKGROUNDS / TEOPETИЧHI ОСНОВИ ДОСЛІДЖЕННЯ}

The research is based on:

- The psychology of inner freedom (G. Ball, V. Chernobrovkina [9], etc.) and The capabilities approach (A. Sen [15], C. Graham [13], etc.) which views the goals of development as substantive freedom-the ability of people to live the lives that they themselves value;

- Subjective well-being as a cognitive-judgmental process (E. Diener, D. Kahneman [11], etc.);

- The theory of self-determination: autonomy, competence and connections with others (R. Ryan, E. Deci [14], etc.).

\section{RESEARCH METHODS / МЕTОДИ ДОСЛІДЖЕННЯ}

The research have been used theoretical (theoretical analysis of literature) and practical psychological methods. The following research instruments have been used: a) Index of psychological safety of educational environment (author I. Baeva [1], modified by O. Bondarchuk); b) Factual Autonomy Scale (FAS, P. Spector, S. Fox, modified by S. Topolov [8]); c) author's method of determining the subjective value of personality characteristics of pedagogical employees [3]; d) The self-efficacy scale (M. Sherer, J.E. Maddux, modified by A. Boyarintseva; f) The Satisfaction With Life Scale (SWLS, E. Diener et all [11]).

The obtained data were analyzed using correlation, ANOVA (SPSS-21.0).

The sample included 500 teachers of secondary school from different regions of Ukraine of whom $85,5 \%$ were females and $14.5 \%$ males. The respondents were divided into four groups according to the length of their service: less than 5 years (19,6\% of the respondents), 5-15 years (19,1\%), 15-25 years $(25,5 \%)$, over 25 years $(35,8 \%)$.

\section{RESEARCH RESULTS / РЕЗУЛЬTАТИ ДОСЛІДЖЕННЯ}

According to the results of the theoretical analysis of literature, it is determined that inner freedom of personality is a cognitive and semantic 
experience that accumulates in itself the experience of relations of an individual with the world, relations with other people and attitudes towards oneself, acquired throughout life [9].

This implies: 1) an implicit positive emotional assessment by the subject of himself and the world, which constitutes the basic sense of the reliability of the world; 2) the perception of yourself as a person capable of acting adequately and successfully; 3) conviction of the right to choose one's own and personal responsibility for own actions and, at the same time, non-interference in those affairs and events that are the sphere of self-determination and responsibility of other people or social groups; 4) awareness of the possibilities and limits of the influence of the world on person and person on the world; 5) spiritual selfdetermination in the value relation to the world, people, themselves; understanding of one's own uniqueness and at the same time unity with the world, etc. (B. Bratus [5], G. Ball [7]; V. Chernobrovkina [9], etc.).

As a result of the empirical study of inner freedom indicators, the insufficient level of their manifestation in a fairly large number of teachers has been found.

At the first stage of the investigation on the SWLS scale the average value of teachers' well-being was 23.3 points with a standard deviation of 4.8. The possible range of scores on the questionnaire is from 5 (low satisfaction) to 35 (high satisfaction). Teachers' well-being was shown to correlate with gender and work experience: the longer the service, the less well-being become; female, especially those with less professional work experience, have less well-being than male $(\rho<0.01)$

It should be noted that high and fit levels of life satisfaction were found in a mere $50 \%$ respondents (tab. 1 ).

Table 1

Groups of teachers in relation to levels of their well-being

\begin{tabular}{|l|c|}
\hline \multicolumn{1}{|c|}{ Levels of well-being } & \% of the respondents \\
\hline Low & 18.9 \\
\hline Reduced & 31.4 \\
\hline Fit & 21.0 \\
\hline High & 28.7 \\
\hline
\end{tabular}

This is a rather sad fact because subjective well-being is a generalized and relatively persistent feeling that has a special significance for the individual. It is to a great extent that it determines the characteristics of the dominant mental state: a favorable state - harmonic mental processes, successful behavior that supports mental and physical health, or, conversely, unfavorable health [11]. This suggests that the perception of the reliability of the world as well as emotional assessment by the subject of himself and the world is not sufficiently positive. 
Also, self-efficacy of teachers has been investigated as one of the empirical indicator of their inner freedom. Indeed, a person with a high level of self-efficacy feels self-confidence, is less dependent on pressure of a stressful situation, respects himself and uses constructive strategies in dealing with difficult life situations in activities and social interaction [4].

According to the results of the study, an insufficient level of self-efficacy was found for a significant number of pedagogical workers, whose high level was determined only in $33,6 \%$ of the respondents, while other educators are characterized by average $(27,3 \%)$ and low (39\%) levels of self-efficacy [2].

At the next stage of the investigation the distribution of teachers was determined by the levels of their professional autonomy (tab. 2).

\section{Table 2}

Groups of teachers in relation to levels of their factual autonomy

\begin{tabular}{|l|c|}
\hline \multicolumn{1}{|c|}{ Levels of factual autonomy } & \% of the respondents \\
\hline Low & 15.7 \\
\hline Below average & 19.5 \\
\hline Average & 47.3 \\
\hline Over average & 17.5 \\
\hline High & 0.0 \\
\hline
\end{tabular}

As can be seen from Table 2, the low level of professional autonomy was found in $15,7 \%$ of the teachers surveyed, below the average $-19,5 \%$, the average $47,3 \%$, higher than the average $-17,5 \%$. There were no teachers with a high level of professional autonomy.

The dependence of the indicators of professional autonomy of pedagogical staff on their gender and work experience is established: with the increase of professional experience, the professional autonomy of male teachers increases, and on the contrary, it becomes smaller among female teachers $(\rho<0.01)$.

In addition, according to the results of factor analysis of the data of the author's technique, features of the subjective value of personality characteristics of educators were revealed. At the same time, the high level of manifestation of the leading (first and second) factors «Spirituality» and «Subjectivity» was established in less than half of the subjects $(41,5 \%$ and $36,9 \%$ respectively) [2]. Thus, it is a question of the insufficient level of value for educators in the development of spirituality and other personality characteristics, which are of particular importance in the context of internal freedom of teachers.

On the other hand, the essence and features of a psychologically safe educational environment are determined. First of all, it has been established that the educational environment is a subsystem of the socio-cultural environment as a set of factors, circumstances, situations that historically formed as the integrity of 
the specially organized conditions for the development of the personality of the subjects of the educational process [12].

Vectors of the analysis of the psychological security of the educational environment are singled out: 1) freedom - dependence (whose interests are priority in this educational environment - personality or group; who is adapted in the process of pedagogical interaction - a teacher to a pupils or a pupils to a teacher; 2) activity - passivity (whether the initiative of the participants in the educational process is stimulated, whether positive or negative feedback is received among the participants in the educational process, etc.).

Accordingly, the main features of a psychologically safe educational environment include: a) human-centered, humanistic orientation; b) interaction, free of manifestations of psychological violence; c) the referential significance and involvement of each subject of the educational process to the design and maintenance of the psychological comfort of the educational environment, etc [1], [6], [10].

At the next stage of the empirical investigation the Index of psychological safety of educational environment found out a mere $20,8 \%$ of the respondents to identify the psychological safety of their educational environment as completely safe, $45,4 \%$ - as safe (table 3 ).

It should be noted that $21.2 \%$ of the teachers are estimated the psychological safety of their educational environment as uncertain, 10,8\% - as unsafe, 1,8 - as completely unsafe.

The investigation found weak statistically significant correlations between the groups of teachers with different psychological safety of educational environment and their gender: males feel more psychologically safety than females $(\mathrm{p}<0.01)$.

Table 3

\section{Groups of teachers in relation to levels of psychological safety of their educational environment}

\begin{tabular}{|l|c|}
\hline \multicolumn{1}{|c|}{$\begin{array}{c}\text { Levels of psychological safety of educational } \\
\text { environment }\end{array}$} & \% of the respondents \\
\hline Completely unsafe & 1.8 \\
\hline Unsafe & 10.8 \\
\hline Uncertain & 21.2 \\
\hline Safe & 45.4 \\
\hline Completely safe & 20.8 \\
\hline
\end{tabular}

This result, in our opinion, is a consequence of gender inequality in our society. At the same time, recently, positive trends in solving this problem should be noted. 
In addition, statistically significant correlations between psychological safety of educational environment and professional characteristics (length of professional service and positions) of teachers have been established. In particular: the longer the length of professional service, the less psychological safety of teachers $(p<0.01)$. It should also be noted that managers feel more psychologically safety than ordinary teachers $(\mathrm{p}<0.01)$.

At the final stage the indicators of teachers' inner freedom was found to positively correlate with the respondents' psychological safety of their educational environment In particular, there are correlations between psychological safety of educational environment and indicators of teachers' inner freedom such as selfefficacy, the personal value of inner freedom, professional autonomy and subjective well-being $(\mathrm{p}<0.01)$.

The investigation findings can be used in to elevate Ukrainian teachers' inner freedom taking into account the necessity of creating a psychologically safe educational environment. In our opinion, the main conditions for creating a psychologically safe educational environment include:

- monitoring of the psychological safety of the educational environment and participants in the educational process;

- psychological and managerial counselling of educational institutions' managers regarding the management of the educational environment in the context of psychological safety;

- organization of special psychological training of participants in the educational process;

- training of practical psychologists to psychological support of the interaction of participants in the educational process in a safe educational environment.

\section{CONCLUSIONS AND PROSPECTS FOR FURTHER RESEARCH / ВИСНОВКИ ТА ПЕРСПЕКТИВИ ПОДАЛЬШИХ ДОСЛІДЖЕНЬ}

Psychological safety of educational environment is a significant factor in the personal development of teachers, in particular, their inner freedom. As a result of the empirical study of inner freedom of teachers of secondary schools from all regions of Ukraine, are found an insufficiently high level of inner freedom and psychological safety of educational environment for a significant number of educators.

There are correlations between psychological safety of educational environment and indicators of teachers' inner freedom such as self-efficacy, the personal value of inner freedom, professional autonomy and subjective well-being. 
The investigation findings can be used in to elevate inner freedom Ukrainian teachers' by means of special training courses. This can be effectively done in the system of post-graduate pedagogical training.

Prospects for further research. It would be valuable to find out the indicators of inner freedom of teachers of institution of higher education and the safety of their educational environment. The theoretical background, development and testing of the program to promote the development of internal freedom of teachers in postgraduate education seems expedient.

\section{REFERENCES REFERENCES (TRANSLATED AND TRANSLITERATED) / СПИСОК ВИКОРИСТАНИХ ДЖЕРЕЛ}

[1] И. Баева и И.Якиманская, «Мониторинг психологической безопасности образовательной среды и качества образования в условиях модернизации», Психолого-педагогические исследования, № 1, 2013. [Электронный ресурс].

Доступно: http://psyjournals.ru/psyedu_ru/2013/n1/59067.shtml

[2] О. І. Бондарчук, «Психологічно безпечне освітнє середовище як чинник саморозвитку педагогічних працівників», Психолого-педагогічний супровід професійної підготовки та підвищення кваліфікації фахівців в умовах трансформації освіти, на III Всеукр. наук-практ. конф. з міжнар. участю (м. Київ, 25 трав. 2018 р.). Київ, Українеа: ДВНЗ «Ун-т менедж. освіти», 2018, 120 с., с. 12-16. [Електронний ресурс]. Доступно: http://umo.edu.ua/konferenciji

[3] О. І. Бондарчук, Соціально-психологічні основи особистісного розвитку керівників загальноосвітніх навчальних закладів у професійній діяльності. Київ, Україна: Наук. світ, 2008, с. 79-82.

[4] А. В. Бояринцева, «Мотивационно-когнитивные характеристики личности молодого предпринимателя», дис. канд. наук. Москва, Россия, 1995, 249 c.

[5] Б. С. Братусь, «Образ человека в гуманитарной, нравственной и христианской психологии», Психология $c$ человеческим лищом: гуманистическая перспектива в постсоветской психологии; Д. А. Леонтьева, В. Г. Щур, Ред. Москва, Россия: Смысл, 1997, с. 67-91.

[6] О.А.Елисеева, «Субъективное благополучие подростков и психологическая безопасность образовательной среды», Психологическая наука и образование: электрон. журнал, № 3, 2011. [Электронный ресурс]. Доступно: www.psyedu.ru

[7] Л.3.Сердюк, «Психологічні основи самодетермінації особистості в концепції внутрішньої свободи Г. О. Балла», Гуманний розум: зб. статей (присвячено пам'яті Георгія Олексійовича Балла); Ін-т психології 
ім. Г. С. Костюка НАПН України; [0. В.Завгородня, В. Л. Зливков, Ред.; уклад. С. О. Лукомська, О. В. Федан,]. Київ, Україна: Педагогічна думка, c. 142-148, 2017.

[8] Є. В. Тополов, Професійна агресивність особистості. Київ, Україна: Слово, 2011, с. 379-380.

[9] В.А. Чернобровкіна, «Внутрішня свобода особистості: досвід психологічного дослідження», Наукові записки НаУКМА. Педагогічні, психологічні науки та соціальна робота, т. 175, с. 47-52, 2015.

[10] Т.Н. Щербакова, «К вопросу о структуре образовательной среды учебных учреждений», Молодой ученый, № 5, с. 545-548, 2012.

[11] E. Diener, Daniel Kahneman, John Helliwell, «International Differences in Well-Being», Oxford University Press, 512 p., 2010.

[12] International Handbook of Research on Environmental Education. Eds.: R. B. Stevenson, M. Brody, J. Dillon, A. E. J. Wals. Routledge, 2014, 592 p.

[13] Carol Graham and Stefano Pettinato, Happiness and Hardship. Opportunity and Insecurity in New Market Economies. Brookings Institution Press, 2002, $208 \mathrm{p}$.

[14] R. M. Ryan, Edward L. Deci, «Self-Regulation and the Problem of Human Autonomy: Does Psychology Need Choice, Self-Determination, and Will?», Journal of Personality, vol. 74, Is. 6, p. 1557-1586, 2006.

[15] A. K. Sen, «Human rights and capabilities», Journal of Human Development, № 6(2), p. 151-166, 2005.

\title{
ОСОБЛИВОСТІ ВНУТРІШНЬОЇ СВОБОДИ ВЧИТЕЛІВ З РІЗНИМИ РІВНЯМИ ПСИХОЛОГІЧНОЇ БЕЗПЕКИ ЇХНЬОГО ОСВІТНЬОГО СЕРЕДОВИЩА
}

\author{
Бондарчук Олена Іванівна, \\ доктор психологічних наук, професор, \\ завідувач кафедри психології управління \\ Центрального інституту післядипломної освіти \\ ДВНЗ «Університет менеджменту освіти», \\ Київ, Україна. \\ ORCID iD: https://orcid.org/0000-0003-3920-242X \\ bei.07@ukr.net
}

Анотація. У статті розглянуто проблему взаємозв'язку між внутрішньою свободою вчителя та психологічною безпекою освітнього середовища школи. Визначено ключові протиріччя позиції українських вчителів, які можуть зменшити їхню внутрішню свободу та негативно вплинути на психологічну безпеку освітнього середовища. Розкрито сутність та основні ознаки внутрішньої свободи вчителя та 
Вісник післядипломної освіти. Випуск 7(36) «Серія «Соціальні та поведінкові науки» https://doi.org/10.32405/2522-9931

психологічної безпеки освітнього середовища закладів середньої освіти.

Досліджено взаємозв'язок між внутрішньою свободою вчителів та безпекою освітнього середовища. Визначено особливості та фактори внутрішньої свободи вчителя та психологічної безпеки їхнього освітнього середовища. У результаті емпіричного дослідження внутрішньої свободи вчителів середніх шкіл з усіх регіонів України виявлено недостатньо високий рівень внутрішньої свободи та психологічної безпеки освітнього середовища для значної кількості освітян. Визначено особливості проявів внутрішньої свободи вчителів та психологічної безпеки навчального середовища школи в залежності від їх статі та досвіду роботи.

Показано, що психологічна безпека освітнього середовища $є$ важливим фактором особистісного розвитку вчителя, зокрема, їхньої внутрішньої свободи. Зокрема, визначено, що існують кореляційні зв'язки між психологічною безпекою освітнього середовища та індикаторами внутрішньої свободи вчителя, такими як самоефективність, особистісна цінність внутрішньої свободи, професійна автономність та суб'єктивне благополуччя освітян.

Констатовано, що результати дослідження можуть бути використані для розвитку внутрішньої свободи українських вчителів за допомогою спеціальних навчальних курсів у системі післядипломної педагогічної освіти.

Ключові слова: вчитель; внутрішня свобода; освітнє середовище; психологічна безпека; суб'єктивне благополуччя.

\title{
ОСОБЕННОСТИ ВНУТРЕННЕЙ СВОБОДЫ УЧИТЕЛЕЙ С РАЗНЫМИ УРОВНЯМИ ПСИХОЛОГИЧЕСКОЙ БЕЗОПАСНОСТИ ИХ ОБРАЗОВАТЕЛЬНОЙ СРЕДЫ
}

\author{
Бондарчук Елена Ивановна, \\ доктор психологических наук, профессор, \\ заведующая кафедрой психологии управления \\ Центрального института последипломного образования \\ ГВУЗ «Университет менеджмента образования», \\ Киев, Украина. \\ ORCID iD: https://orcid.org/0000-0003-3920-242X \\ bei.07@ukr.net
}

Аннотация. В статье рассматривается проблема соотношения внутренней свободы учителя и психологической безопасности образовательной среды школы. Определены ключевые противоречия позиции украинских педагогов, которые могут снизить их внутреннюю 
свободу и негативно повлиять на психологическую безопасность образовательной среды. Раскрываются сущность и основные признаки внутренней свободы учителя и психологической безопасности образовательной среды учреждений среднего образования.

Исследована связь между внутренней свободой учителей и безопасностью образовательной среды. Установлены отличительные черты и факторы внутренней свободы учителей и психологической безопасности их образовательной среды. В результате эмпирического исследования внутренней свободы учителей общеобразовательных школ из всех регионов Украины, выявлен недостаточно высокий уровень внутренней свободы и психологической безопасности образовательной среды для значительного числа педагогов. Определены особенности проявления внутренней свободы учителей и психологической безопасности образовательной среды школы в зависимости от их пола и опыта работы.

Показано, что психологическая безопасность образовательной среды является значимым фактором личностного развития педагогов, в частности, их внутренней свободы. Установлено, что существует статистически значимая связь между показателями психологической безопасности образовательной среды и внутренней свободы учителя, такими как самоэффективность, личная ценность внутренней свободы, профессиональная автономия и субъективное благополучие.

Констатировано, что результаты исследования могут быть использованы для развития внутренней свободы украинских учителей с помощью специальных учебных курсов в системе последипломного педагогического образования.

Ключевые слова: учитель; внутренняя свобода; образовательная среда; психологическая безопасность; субъективное благополучие.

\section{REFERENCES (TRANSLATED AND TRANSLITERATED)}

[1] I. Baeva i I.YAkimanskaya, «Monitoring psihologicheskoj bezopasnosti obrazovatel'noj sredy i kachestva obrazovaniya v usloviyah modernizacii», Psihologo-pedagogicheskie issledovaniya, № 1, 2013. [EHlektronnyj resurs]. Dostupno: http://psyjournals.ru/psyedu_ru/2013/n1/59067.shtml

[2] O. I. Bondarchuk, «Psykholohichno bezpechne osvitnie seredovyshche yak chynnyk samorozvytku pedahohichnykh pratsivnykiv», Psykholohopedahohichnyi suprovid profesiinoi pidhotovky ta pidvyshchennia kvalifikatsii fakhivtsiv v umovakh transformatsii osvity, na III Vseukr. nauk.prakt. konf. z mizhnar. uchastiu (m. Kyiv, 25 trav. 2018 r.). Kyiv, Ukrainea: 
DVNZ «Un-t menedzh. osvity», 2018, 120 s., s. 12-16. [Elektronnyi resurs]. Dostupno: http://umo.edu.ua/konferenciji

[3] O. I. Bondarchuk, Sotsialno-psykholohichni osnovy osobystisnoho rozvytku kerivnykiv zahalnoosvitnikh navchalnykh zakladiv u profesiinii diialnosti. Kyiv, Ukraina: Nauk. svit, 2008, s. 79-82.

[4] A. V. Boyarinceva, «Motivacionno-kognitivnye harakteristiki lichnosti molodogo predprinimatelya», dis. kand. nauk. Moskva, Rossiya, 1995, 249 s.

[5] B. S. Bratus', «Obraz cheloveka v gumanitarnoj, nravstvennoj i hristianskoj psihologii», Psihologiya s chelovecheskim licom: gumanisticheskaya perspektiva v postsovetskoj psihologii; D. A. Leont'eva, V.G.SHCHur, Red. Moskva, Rossiya: Smysl, 1997, s. 67-91.

[6] O. A. Eliseeva, «Sub"ektivnoe blagopoluchie podrostkov i psihologicheskaya bezopasnost' obrazovatel'noj sredy», Psihologicheskaya nauka i obrazovanie: ehlektron. zhurnal, № 3, 2011. [EHlektronnyj resurs]. Dostupno: www.psyedu.ru

[7] L.Z. Serdiuk, «Psykholohichni osnovy samodeterminatsii osobystosti v kontseptsii vnutrishnoi svobody H. O.Balla», Humannyi rozum: zb. statei (prysviacheno pamiati Heorhiia Oleksiiovycha Balla); In-t psykholohii im. H. S. Kostiuka NAPN Ukrainy; [O. V. Zavhorodnia, V. L. Zlyvkov, Red.; uklad. S. O. Lukomska, O. V. Fedan,]. Kyiv, Ukraina: Pedahohichna dumka, s. 142-148, 2017.

[8] Ye. V.Topolov, Profesiina ahresyvnist osobystosti. Kyiv, Ukraina: Slovo, 2011, s. 379-380.

[9] V.A.Chernobrovkina, «Vnutrishnia svoboda osobystosti: dosvid psykholohichnoho doslidzhennia», Naukovi zapysky NaUKMA. Pedahohichni, psykholohichni nauky ta sotsialna robota, t. 175, s. 47-52, 2015.

[10] T. N. SHCHerbakova, «K voprosu o strukture obrazovatel'noj sredy uchebnyh uchrezhdenij», Molodoj uchenyj, № 5, s. 545-548, 2012.

[11] E. Diener, Daniel Kahneman, John Helliwell, «International Differences in WellBeing», Oxford University Press, 512 p., 2010.

[12] International Handbook of Research on Environmental Education. Eds.: R. B. Stevenson, M. Brody, J. Dillon, A. E. J. Wals. Routledge, 2014, 592 p.

[13] Carol Graham and Stefano Pettinato, Happiness and Hardship. Opportunity and Insecurity in New Market Economies. Brookings Institution Press, 2002, $208 \mathrm{p}$.

[14] R. M. Ryan, Edward L. Deci, «Self-Regulation and the Problem of Human Autonomy: Does Psychology Need Choice, Self-Determination, and Will?», Journal of Personality, vol. 74, Is. 6, p. 1557-1586, 2006.

[15] A. K. Sen, «Human rights and capabilities», Journal of Human Development, № 6(2), p. 151-166, 2005. 